\title{
MASA DEPAN WAJAH ISLAM INDONESIA Kajian atas Islam Moderat-Progresif
}

\author{
Budhy Munawar-Rahman \\ Sekolah Tinggi Filsafat Driyarkara \\ Jl. Komp. Cemp. Putih Indah No.100A, RT.1/RW.7, Kec. Cemp. Putih, Jakarta Pusat, \\ Email.budhy.rachman@asiafoundation.org
}

\begin{abstract}
Abstrak
Tulisan ini secara umum akan membahas pemikiran dan gerakan kelompok yang disebut "Islam Moderat-Progresif" dan kelembagaan mereka - tempat di mana mereka menyemai ide-ide tentang Islam yang inklusif dan moderat, atau "Islam yang Ramab” (the Smiling Islam). Kelembagaan kalangan Islam Moderat-Progresif ini ada dalam pengaruh-langsung atau tidak langsung —orientasi pemikiran dan gerakan dua payung besar Islam Indonesia yaitu Nabdlatul Ulama (NU), yang biasa disebut "tradisionalis", yang mengklaim memiliki 40 juta umat, dan Mubammadiyah, yang biasa disebut "modernis" yang mengklaim memiliki 30 juta umat. Jika digabung, NU dan Mubammadiyah mewakili 70 juta umat Islam di Indonesia. Kelompok. Muslim lain tersebar dalam berbagai organisasi Islam yang lebih kecil seperti Persatuan Islam (PERSIS) dan Persatuan Umat Islam (PUI) di Jawa Barat, Nahdlatul Wathan di Nusa Tenggara Barat, Darul Dakwah wal Irsyad (DDI) di Sulawesi Selatan, Al-Kayrat di Sulawesi Tengah, Al-Washliyah di Sumatera Utara, Perti di Sumatera Barat, dan kelompok-kelompok tarekat yang berjumlah ratusan di seluruh Indonesia.
\end{abstract}

Kata Kunci: indonesia, islam moderat, islam progresif

\section{Abstract}

This paper will generally discuss the thoughts and movements of the group called "Moderate-Progressive Islam" and their institutions - a place where they sow ideas about an inclusive and moderate Islam, or "Friendly Islam" (the Smiling Islam). The institutionalization of Moderate-Progressive Muslims is under the influence - directly or indirectly - of the orientation of the thoughts and movements of the two major Indonesian Islamic umbrellas, namely the Nahdlatul Ulama (NU), which is commonly called "traditionalist", which claims to have 40 million followers, and Muhammadiyah, which commonly called "modernists" who claim to have 30 million people. Combined, NU and Mubammadiyah represent 70 million Muslims in Indonesia. Other Muslim groups are scattered in smaller Islamic organizations such as the Islamic Union (PERSIS) and the Islamic Community Association (PUI) in West Java, Nahdlatul Wathan in West Nusa Tenggara, Darul Dakwah wal Irsyad (DDI) in South Sulawesi, Al-Kayrat in Central Sulawesi, Al-Washliyah in North Sumatra, Perti in West Sumatra, and hundreds of tarekat groups throughout Indonesia.

Keywords: indonesia, moderate islam,progressive islam

\section{PENDAHULUAN}

Istilah “Islam Moderat-Progresif” sekarang sering dipakai oleh kalangan muda NU maupun Muhammadiyah yang mencoba mengembangkan lebih mendalam — atau tepatnya lebih progresifgagasan moderasi ("Islam Moderat") yang merupakan paham dasar NU maupun Muhammadiyah. Islam Moderat-Progresif dimaksudkan untuk memberi penekanan utama kepada pengembangan ilmu pengetahuan, diskursus keadilan, keterbukaan, sikap toleransi, dan perlunya membangun integritas moral kaum Muslim dalam membangun kebangsaan Indonesia. Islam Moderat-Progresif bukan hanya memahami Islam sebagai agama, tetapi lebih jauh Islam sebagai peradaban. ${ }^{1}$

${ }^{1}$ Ahmad Gaus AF, "Islam Progresif: Wacana Pasca Arus Utama (Peta Pemikiran dan Gerakan Islam di Indonesia)", dalam, Jurnal Tashwirul Afkear, Edisi No. 22 
Istilah "Islam Moderat-Progresif" yang merupakan pengembangan lebih mendalam dari pemikiran dan posisi "Islam moderat", sering diperhadapkan dengan "Islam Radikal" di satu sisi, dan "Islam liberal" yang jauh lebih "sekuler" di sisi lain. Tetapi walaupun demikian antara pemikiran Islam Moderat-Progresif dan Islam Liberal kadang bisa dipertukarkan. ${ }^{2}$ Sarjana yang pertama kali menggunakan kedua istilah Islam Moderat-Progresif dan Islam Liberal sekaligus di Indonesia adalah Greg Barton. Istilah ini menggambarkan suatu gerakan mutakhir dalam Islam Indonesia yang melampaui gerakan Islam tradisional dan gerakan Islam modern. Gerakan progresif liberal yang dimaksud adalah gerakan yang Fazlur Rahman (almarhum, Guru Besar University of Chicago) menyebut "Islam neomodernis"-yang di Indonesia dikembangkan oleh murid-muridnya, yaitu Ahmad Syafii Maarif dan Nurcholish Madjid, belakangan Abdurrahman Wahid, M. Dawam Rahardjo, dan Djohan Effendi masuk dalam kategori ini. ${ }^{3}$

Gerakan dan pemikiran Islam ModeratProgresif yang akan dianalisis dalam tulisan ini, akan memperlihatkan berbagai penafsiran teologis berkaitan dengan problem-problem kontemporer, terutama isu Islam dan demokrasi. Dalam mengembangkan Islam Moderat-Progresif mereka melakukan:

Pertama, pembaruan pemahaman keislaman (khususnya fikih atau hukum Islam), terutama dalam rangka menyelaraskan pemahaman keagamaan dengan perkembangan kekinian. Mereka menyadari diperlukan sebuah "fikih baru" yang mampu menjawab problem kemanusiaan dewasa ini. Misalnya umat Islam dituntut untuk mengembangkan fikih yang bisa berdialog dengan isu demokrasi (fikih demokrasi), pluralisme (fikih toleransi, atau fikih lintas agama), liberalisme

Tahun 2007, h. 96. Sebagai contoh Zuhairi Misrawi dan Novriantoni, keduanya adalah pemikir muda dari tradisi NU menulis buku Doktrin Islam Progresif Memahami Islam Sebagai Ajaran Rahmat (Jakarta:LSIP, 2004), dan Zuly Qodir dkk. (ed.), Muhammadiyah Progresif Manifesto Pemikiran Kaum Muda (Yogyakarta: Lesfi-JIMM, 2007). Dr. Zuly Qodir adalah intelektual Muhammadiyah.

2 Ahmad Gaus AF, "Islam Progresif: Wacana Pasca Arus Utama”, Jurnal Tashwirul Afkar, Edisi No. 22 Tahun 2007, h. 96

${ }^{3}$ Ibid., h. 97 (fikih politik, fikih hak asasi manusia, fikih gender), dan seterusnya. ${ }^{4}$

Kedua, sosialisasi informasi yang benar tentang Islam. Belakangan ini, suara atas nama Islam direpresentasikan oleh kelompok-kelompok yang tidak mewakili sebagian besar umat Islamyaitu kelompok yang dalam tulisan ini disebut "Islam Radikal". Umat Islam secara keseluruhan mendapatkan stigma karena citra Islam Radikal ini. Alih-alih ingin berkompetisi di pentas global, umat Islam dirundung citra buruk di mata dunia dengan stigmatisasi radikalisme, bahkan terorisme. Islam diidentikkan dengan seluruh tindakan yang bernuansa kekerasan. Karena itulah pemikir Islam Moderat-Progresif ini bekerja keras menghadirkan wajah Islam Moderat-Progresifdalam arti Islam yang penuh kedamaian, toleran, moderat, bahkan liberal, dan berkeadaban, dalam satu kata "Islam Ramah".

Pada dasarnya, kehadiran para intelektual Muslim moderat-progresif pada pertengahan 1990-an ini memiliki garis kesinambungan ideologis maupun sosiologis dengan gerakan Islam terdahulu yang sering dinamakan gerakan Islam Tradisional dan Islam Modern yang muncul pada awal abad ke-20. ${ }^{5}$ Pemikiran tradisional dan modern yang diwakili mainstream-nya oleh NU dan Muhammadiyah ${ }^{6}$ dalam perjalanan sejarahnya

${ }^{4}$ Kehadiran fikih seperti ini menurut mereka sangat penting untuk membuktikan relevansi Islam dalam dunia yang lebih plural dan global. Dalam menghadapi realitas global, pemikir Islam sejatinya mampu memberikan alternatif-alternatif bagi umat Islam yang bersifat substantif, bukan hanya simbolik. Islam, menurut mereka adalah agama yang menghendaki kemajuan dan menolak keterbelakangan. Karena itulah mereka-lewat lembaganya masing-masing, dan pendekatannya yang khasmengembangkan pandangan-pandangan keagamaan yang bersifat progresif.

${ }^{5}$ Mohamad Ali, Islam Muda Liberal, Post-Puritan, PostTradisional (Yogyakarta: Apeiron Philotes, 2006), h. 33.

${ }^{6}$ Dalam diskursus pemikiran Islam pertentangan antara Islam ideologis dan Islam kultural, atau Islam literal versus Islam liberal, kelihatannya menjadi catatan sejarah sepanjang zaman. Uniknya, baik yang literal maupun yang liberal sama-sama ada dalam tubuh NU maupun Muhammadiyah. Jadi ada Muhammadiyah literal yang identik dengan "Kanan", dan ada Muhammadiyah Liberal yang identik dengan "Kiri". Begitu juga di NU: Ada NU "Kanan" dan NU "Kiri". Pemetaan tersebut sudah sering dikemukakan para ahli Islam Indonesia-apalagi untuk fenomena "Islam Radikal" seperti MMI, FPI, HTI, Ikhwanul Muslimin, dsb. yang biasa diidentifikasi sebagai Islam "Kanan". Mereka memiliki kesadaran yang tinggi dan 


\section{NUSANTARA; Journal for Southeast Asian Islamic Studies}

Vol. 15, No. 1, Juni 2019

telah memunculkan gairah pemikiran baru melalui pembacaan kritis terhadap tradisi mereka sendiri: di Muhammadiyah mereka melakukan kritik terhadap bangunan nalar Muhammadiyah; dan di NU juga melakukan kritik terhadap bangunan nalar NU. Kritisisme mereka melampaui teks. Mereka melakukan penafsiran, bahkan dekonstruksi pemikiran. Generasi baru yang kritis itu lalu memunculkan kelompok-kelompok progresif yang melahirkan pembaruan-pembaruan melalui sekelompok generasi 90 -an. ${ }^{7}$ Secara umum kecenderungan ideologis mereka memang bersemangat kritis atas teks keagamaan, dekonstuksionis, dan dalam batas-batas tertentu bercorak kekiri-kirian. ${ }^{8}$

Dari rahim NU dan Muhammadiyah ini lahirlah komunitas-komunitas Islam ModeratProgresif yang memiliki fokus dan strategi yang berbeda di antara satu dan lain, dan mereka terus memperluas isu-isunya sejalan dengan perkembangan ide-ide baru, namun sebenarnya mereka masih berada dalam tradisi moderat kedua organisasi massa ini. ${ }^{9}$ Di era pasca reformasi, ketika muncul banyak kelompok Islam radikal, NU dan Muhammadiyah sering dianggap kelompok moderat dan dipercaya sebagai kekuatan civil society yang dapat meredam radikalisme dan militanisme Islam yang muncul bersamaan dengan keterbukaan sosial politik era reformasi. Mereka-NU dan Muhammadiyahmemproduksi Islam yang moderat, inklusif, dan progresif. Dari sini kemudian NU dan

termotivasi kuat secara ideologis untuk meneguhkan dirinya sebagai pelurus terhadap praktik-praktik keagamaan yang dianggap "tidak Islami", sehingga melahirkan ekslusivisme dan sektarianisme yang militan. Karena itu kelompok ini juga sangat sensitif terhadap pemikiran yang diindikasikan sebagai pembawa paham sekulerisme, liberalisme, dan pluralisme. Lihat, Moh. Shofan, "Mencari Format Baru Pluralisme Dari Moral Defensif Ke Moral Ofensif", makalah dipresentasikan pada acara Workshop Pluralisme, Demokrasi dan Civil Society di Puncak Bogor, 6-8 Juni 2007, yang diselenggarakan oleh PSIK Universitas Paramadina.

${ }^{7}$ Nur Khalik Ridwan, "Berharap pada Islam Muda", epilog dalam Mohamad Ali, Islam Muda Liberal, Post-Puritan, Post-Tradisional, h.150.

${ }^{8}$ Nur Khalik Ridwan, Santri Baru, Pemetaan, Wacana Ideologi dan Kritik (Yogyakarta: Gerigi Pustaka, 2004), h. 25.

9 Muhamad Ali, "Gerakan Islam Moderat di Indonesia Kontemporer" dalam Rizal Sukma dan Clara Juwono (ed.), Gerakan dan Pemikiran Islam di Indonesia Kontemporer (Jakarta: CSIS, 2007), h. 211.
Muhammadiyah mengkader para pendukungnya untuk memasuki lembaga-lembaga yang ada di tengah masyarakat, baik itu pendidikan, sosial, politik, ekonomi maupun keagamaan. Berbeda dengan pendukung Islam fundamentalis, atau radikal, pendukung NU dan Muhammadiyah relatif memiliki daya sebar yang tinggi sehingga mereka mengisi seluruh kawasan Indonesia, sampai ke desa-desa. ${ }^{10}$ Itu sebabnya NU dan Muhammadiyah diharapkan mampu memainkan peranan penting dalam proses demokratisasi di Indonesia, karena NU dan Muhammadiyah merupakan organisasi kemasyarakatan Islam yang memiliki keanggotaan dalam jumlah besar serta dapat memainkan peranan yang penting dalam proses demokratisasi, berkomitmen terhadap pluralisme, memperjuangkan keadilan, dan tanggap terhadap kelompok minoritas dan mendukung nilai-nila keadaban dan kebajikan. ${ }^{11}$

Munculnya intelektual muda Islam Indonesia yang progresif bersamaan dengan gelombang reformasi Mei 1998, harus dipandang sebagai bagian dari mata rantai pembaruan dalam sejarah intelektualisme Islam di Indonesia. Kalangan Islam Moderat-Progresif ini melakukan proses pencarian untuk memperbarui cara pandang terhadap Islam dalam konteks dunia yang berubah.

Berikut akan sedikit digambarkan gerakan Islam Moderat-Progresif dari kalangan tradisional yang diwakili oleh NU, dan gerakan Islam modernis yang diwakili oleh Muhammadiyah. Setelah itu kita akan melihat juga gerakan Islam Moderat-Progresif di lingkungan jaringan UIN/IAIN/STAIN se-Indonesia.

\section{“Islam Ramah" di Lingkungan NU}

Di antara lembaga-lembaga Islam ModeratProgresif ("Islam Ramah") dari kalangan tradisional, terutama $\mathrm{NU}^{12}$ yang muncul pasca reformasi adalah: Jaringan Islam Liberal (JIL)

${ }^{10}$ Jamhari dan Jajang Jahroni (peny.), Gerakan Salafi Radikal di Indonesia (Jakata: Rajawali Pers, 2004), h. 235.

${ }^{11}$ Fuad Fachruddin, Agama dan Pendidikan Demokrasi Pengalaman Muhammadiyah dan Nabdlatul Ulama Jakarta: INSEP, 2006), h. 47.

12 Marzuki Wahid, "Post-Tradisionalisme Islam: Gairah Baru Pemikiran Islam di Indonesia”, dalam Jurnal Tashwirul Afkar, Edisi No. 10 Tahun 2001, h. 16. 
Jakarta, yang dimotori oleh Ulil Abshar-Abdallah. Mereka mempunyai sumbangan penting dalam menyuburkan ide-ide Islam Moderat-Progresif tentang demokrasi. melalui program radio, media, iklan layanan masyarakat, dan terbitanterbitan buku. ${ }^{13}$ Kemudian, Lembaga Kajian Islam dan Sosial (LKiS) di Yogyakarta. Komunitas ini memiliki caranya sendiri dalam mengemas program berkaitan dengan Islam dan demokrasi. LKiS menerbitkan buku-buku keislaman kritis dan transformatif, juga melakukan penelitian dan kajian secara regular, pendampingan masyarakat, khususnya mahasiswa, dan menerbitkan selebaran jum'at al-Ikhtilaf. Kemudian LAKPESDAM (Lembaga Kajian dan Pengembangan Sumber Daya Manusia) NU Jakarta dengan jaringannya di seluruh Indonesia. Selain menerbitkan buku, mengadakan pelatihan, penelitian, dan pendampingan masyarakat, LAKPESDAM NU juga menerbitkan jurnal ilmiah Tashwirul Afkar, di mana gagasan-gagasan tentang Islam dan demokrasi diadvokasikan pada pembacanya yang mayoritas adalah intelektual muda NU. Perhimpunan Pengembangan Pesantren dan Masyarakat (P3M) Jakarta telah mengembangkan wacana Islam dan demokrasi dalam bahasa pesantren. Dalam perjalanan organisasinya, P3M cukup berperan mendewasakan masyarakat - khususnya kalangan NU yang berada di pesantren-dalam hal pemikiran progresif Islam, seperti pengembangan argumen Islam untuk demokrasi. ${ }^{14}$

Lembaga-lembaga yang disebut di atas, adalah komunitas ilmiah yang secara intens tidak saja melakukan kajian tetapi juga penelitian atas berbagai pemikiran keagamaan, dan teori-teori sosial. Isu Islam dan demokrasi mendapat perhatian utama. ${ }^{15}$ Sebagian besar latar belakang pendidikan mereka yang bekerja pada lembagalembaga ini, selain sarjana, adalah pondok pesantren salafiyah (tradisional). ${ }^{16}$

${ }^{13}$ www.islamlib.com

14 Muhammad Ali, "Gerakan Islam Moderat di Indonesia Kontemporer”, h. 219-220. Lihat juga Angela Rabasa, et.all. Builing Moderate Muslim networks, khususnya bab "Secular Muslims: A Forgotten Dimension in the War of Ideas" h. 121-138.

${ }^{15}$ Muhammad Ali, ibid., h. 14

16 Sebelum masuk pada jenjang pendidikan tinggi, mereka rata-rata telah menjalani pendidikan di pondokpondok pesantren di desa-desa. Kalangan muda tradisional
Proses menjadi "santri kota" dimulai ketika kalangan muda ini masuk pada jenjang pendidikan tinggi. Sebagian besar di antara mereka masuk ke IAIN atau institusi keagamaan lainnya, sebagai pilihan utama, selain pendidikan di luar jalur pendidikan agama. Kalangan muda NU ini kemudian merasakan bahwa diri mereka berbeda dengan yang lain. Mereka menyadari mempunyai ikatan dengan "Islam Tradisi" (NU) setelah berinteraksi dengan yang lain-terutama yang berasal dari sub-kultur Muhammadiyah atau umum. Latar belakang sebagai penganut lslam Tradisi inilah yang kemudian membentuk identitas diri mereka ketika sudah sarjana, dan bekerja dalam bidang pemikiran Islam di lembaga-lembaga LSM berkultur NU. Mereka membentuk citra tersendiri, terutama dalam konsep pemikiran dan gerakan yang dikembangkannya. Basis organisasi kemahasiswaannya selain di jajaran organisasi NU, juga di PMII (Pergerakan Mahasiswa Islam Indonesia).

Martin van Bruinessen-seorang ahli Islam di Indonesia dari Belanda-melukiskan fenomena ini sebagai hal yang luar biasa dalam fenomena Islam di Indonesia kontemporer, terutama menjelang reformasi.

"[B]anyak di antara orang muda ini berpengalaman dalam berbagai kegiatan pengembangan masyarakat, dan memiliki kepedulian kepada masalah-masalah sosial dan ekonomi. Organisasi mahasiswa yang berafiliasi ke NU, PMII, selama beberapa tahun ini telah menjadi salah satu organisasi

ini menjalani masa-masa menjadi santri di desa dalam dua tahap. Tahap pertama, persentuhan mereka dengan pesantren, didapatkan di lingkungan tempat mereka tumbuh, karena keberadaan pondok pesantren ada di sekitar tempat tinggal mereka. Mereka biasa belajar di dua tempat, sekolah formal (SD) pada pagi hari, dan sore harinya ngaji pada guru-guru agama tertentu, atau mengambil jalur formal lewat Madrasah Ibtidaiyah. Tahap kedua, setamat SD, mereka mondok di pesantren-pesantren tertentu di luar desa mereka. Sebagian besar kalangan muda memilih menjadi santri di pondok-pondok pesantren dengan dua alasan. Pertama, adanya pondok pesantren yang terkenal di daerah tersebut. Kedua, adanya kiai tertentu yang mereka kagumi sebagai pembina di pondok pesantren tempat mereka belajar. Lihat, Nuriyati Samatan, Dinamika Pemikiran Kalangan Muda Nabdlatul Ulama, Tulisan pada Program Pascasarjana Universitas Padjadjaran, Bandung 2007, h. 222-223. 


\section{NUSANTARA; Journal for Southeast Asian Islamic Studies}

Vol. 15, No. 1, Juni 2019

mahasiswa paling dinamis dalam hal perdebatan intelektual. Kontras dengan mahasiswa Islam modernis, anggota PMII biasanya mempunyai penguasaan lebih baik terhadap ilmu tradisional, tetapi bacaan mereka jauh lebih luas dari kurikulum tradisional semata. Sementara mahasiswa modernis masih banyak dipengaruhi para pengarang seperti [Abu A'la al-] Maududi dan Sayyid Qutb. Mahasiswa PMII memperlihatkan minat yang besar kepada para pengarang yang lebih radikal, seperti Hasan Hanafi, filsuf Mesir itu. Diskusidiskusi di lingkungan mereka menjurus ke pokok persoalan keterbelakangan Dunia Ketiga, keadilan ekonomi, dan hak asasi, termasuk pertanyaan yang sulit tentang hakhak perempuan dalam Islam." 17

Secara umum gerakan kaum muda NU ini bersifat liberal dan terbuka, apresiatif terhadap hal-hal baru, tetapi tetap merakyat. Mereka mempunyai sikap toleransi yang tinggi, penghormatan pada hak asasi manusia, dan konsistensi pada penguatan civil society. Menurut Djohan Effendi-yang menulis tulisan doktornya tentang perkembangan kaum muda progresif NU ini pada Deakin University di Australia—salah satu hal yang menarik dan gerakan ini adalah bahwa para kiai muda itu mengembangkan dan mengapresiasi gagasan-gagasan baru dengan berpijak pada tradisi intelektualnya yang kaya. ${ }^{18}$

Keberadaan intelektual muda progresif NU di jalur kultural ini, berbeda dengan kondisi ketika Abdurrahman Wahid memainkan peran dengan menggerakkan struktur NU, menjadi penyeimbang antara dunia pesantren dengan pemikiran ulama yang cenderung konservatif, dan memacu pemikiran-pemikiran progresif. Kalangan muda progresif NU yang saat ini berada di jalur kultural, merupakan arus baru dalam perkembangan "liberal" dalam organisasi tradisional ini. ${ }^{19}$ Barangkali intelektual muda progresif NU yang berada di jalur kultural ini

17 Martin van Bruinessen, NU: Tradisi, Relasi-relasi Kuasa, Pencarian Wacana Baru (Yogyakarta: LKiS, 1997), h. 233-234.

18 Marzuki Wahid, "Post-Tradisionalisme Islam: Gairah Baru Pemikiran Islam di Indonesia”, h. 16.

19 La Ode Ida, "NU Muda, Kaum Progresif dan Sekularisme Baru” (Jakarta: Erlangga, 2004), h. xiv. mempunyai kesadaran intelektual yang begitu mendalam sehingga seolah tidak mau ketinggalan oleh gerakan-gerakan Islam lainnya, yang telah lebih dulu mengalami kemajuan di bidang intelektual, semisal intelektual muda progresif Muhammadiyah yang sekarang juga tumbuh seperti jamur. Pemikir muda progresif NU ini bangkit, dan seolah memahami benar pesan Nurcholish Madjid, bahwa "Ketika bangsa gagal memahami masa lalu, maka yang akan terjadi adalah kemiskinan intelektual." ${ }^{\text {,20 }}$ Menurut Martin van Bruinessen, keberadaan intelektual muda progresif ini yang sekarang menjadi elit baru di lingkungan NU, tidak lepas dari dukungan dan perlindungan sejumlah tokoh dari kalangan elit NU, seperti Fahmi Syaifuddin, Mustofa Bisri dan Abdurrahman Wahid. ${ }^{21}$

Kalangan muda NU ini disebut oleh Ken Miichi sebagai urban intellectual dimulai dari peran penting Abdurrahman Wahid dan Masdar F. Mas'udi, yang merupakan jaringan intelektual "kiri" sekaligus merupakan tokoh terkenal dari NU yang menurutnya mempunyai lima karakter. 22

Pertama, "radikal" (dalam arti "kiri", bukan dalam arti "Islam Radikal" yang akan dibicarakan dalam tulisan ini). Radikalisme kalangan muda NU muncul pada masa awal ketika mereka berkiprah di jalur kultural, dan masih menjadi mahasiswa. Geliat pemikiran dan gerakan mulai nampak "radikal" misalnya di IAIN (sekarang UIN) Sunan Kalijaga Yogyakarta. Mereka inilah yang nantinya yang bergabung dalam LKiS, dan menyebarkan jenis yang pada awal 1990-an terkenal dengan sebutan "Kiri Islam". 23

Kedua, "kritis". Pemikiran kritis ini tidak hanya ditujukan kepada fenomena di luar NU, tetapi juga kritis terhadap kondisi obyektif NU,

20 Nurcholish Madjid, "Jangan Tinggalkan Masa Lalu”, dalam Republika, Jum'at 25 Juni 1999, h. 8. Lihat juga, Yasmin, Modernisasi Pesantren Kritik Nurcholish Madjid Terhadap Pendidikan Islam Tradisional (Jakarta: Quantum Teaching, 2005), h. 128.

21 La Ode Ida, NU Muda, Kaum Progresif dan Sekularisme Baru, Op. cit, h. xiv

22 Nuriyati Samatan, Dinamika Pemikiran Kalangan Muda Nabdlatul Ulama, Opcit., h. 224. Lihat juga, Ken Miichi, "Kiri Islam, Jaringan Intelektual dan Partai Politik: Sebuah Catatan Awal", dalam Jurnal Tashwirul Afkar, Edisi No. 10 Tahun 2001.

${ }^{23}$ Nuriyati Samatan, Ibid., h. 229. 
Budhy Munawar-Rahman: Masa Depan Wajah Islam Indonesia...

atau sebagai otokritik. Kritik yang banyak dilakukan oleh kalangan muda progresif NU adalah kritik wacana, terutama mengkritisi kitab kuning, dan kemapanan berpikir di kalangan ulama maupun kalangan masyarakat Nabdliyin. ${ }^{24}$ Kegiatan ini menurut Andree Feillard, menjadi penting, karena Kitab Kuning tidak pernah dipermasalahkan sebelumnya. Pembacaan kritis ini antara lain dilakukan untuk mencari relevansi sosial dari kitab yang selama ini berada dalam posisi "mapan" bagi kalangan Nabdliyin. Gerakan kritis ini sempat terhenti karena keberatan kalangan ulama konservatif. ${ }^{25}$ Di kemudian hari pembacaan kritis terhadap Kitab Kuning ini dilanjutkan oleh Masdar F. Mas'udi melalui P3M sejak masa reformasi (1998), dan sekarang sudah menjadi tradisi semua pemikir Muslim Progresif satu generasi di bawah Masdar. ${ }^{26}$

Ketiga, gerakan kalangan muda NU progresif ini berada di luar struktur NU. Gerakan pemikiran yang mereka lakukan umumnya diorganisir melalui lembaga swadaya masyarakat (LSM) yang independen. Dalam lembaga-lembaga inilah mereka menghasilkan pemikiran yang kreatif dan mencerahkan. ${ }^{27}$

Keempat, "resisten". Resistensi dilakukan tidak hanya terhadap gerakan yang dalam tulisan ini akan disebut "Islam Radikal" tetapi resistensi juga dilakukan terhadap pengurus $\mathrm{NU}^{28}$

Kelima, gerakan pemikiran intelektual muda progresif NU adalah terbuka. Keterbukaan ini ditunjukkan melalui dialog dan akomodasi

${ }^{24}$ Andree Feillard, NU vis-a-vis Negara; Pencarian Isi, Bentuk dan Makna (Yogyakarta: LKiS, 1999), h. 377

25 Martin van Bruinessen, Opcit., h. 221. Andree Feillard, Ibid., h. 377.

${ }^{26}$ Martin van Bruinessen, Ibid., h. 222.

27 Perkembangan wacana pemikiran di lingkungan NU paska reformasi ini, lihat, Rumadi, Post Tradisionalisme Islam: Wacana Intelektualisme dalam Komunitas NU (Jakarta: Fahmina Institute, 2008).

28 Resistensi terhadap pengurus NU pernah dilakukan secara terbuka pada Musyawarah Besar Warga Nahdlatul Ulama pada 8-10 Oktober 2004 di Pondok Pesantren Babakan Ciwaringin, Cirebon. Gerakan yang mereka sebut sebagai "Kiri radikal terhadap elit-elit "Nahdlatul Ulama"' itu dihadiri oleh ribuan kalangan muda NU dari berbagai daerah. Kegiatan yang dimotori oleh kalangan muda NU ini, didukung oleh beberapa kyai sepuh berpengaruh, antara lain Kyai Abdullah Abbas, Dr. Malik Madani, Tuan Guru Turmudi. Lihat, Nuriyati Samatan, Dinamika Pemikiran Kalangan Muda Nabdlatul Ulama, Opcit., h. 239 pemikiran seperti pemikiran Timur kontemporer (Islam Timur Tengah), pemikiran Barat kritis (seperti sosial Barat), dan akomodasi terhadap khazanah lokal, baik lokalitas yang merupakan tradisi NU, maupun khazanah lokal dalam masyarakat tradisi Indonesia. Akomodasi ini diharapkan akan menghasilkan pemikiran Islam Indonesia yang unik, yang secara konseptual mampu membawa serta lokalitas menuju kemodernan. ${ }^{29}$ Mereka ingin mengglobalkan Islam (globalized Islam) Indonesia.

Munculnya komunitas Islam ModeratProgresif NU sekarang ini telah merambah secara luas, dimulai dari aktivitas mahasiswa di dalam kampus sampai membentuk lembaga swadaya masyarakat baru dengan sejumlah agenda untuk melakukan transformasi sosial, baik dalam bentuk kegiatan diskusi wacana kritis, gerakan sosial, gerakan kultural, penelitian ilmiah dan penerbitan buku.

\section{"Islam Ramah" di Lingkungan Muhammadiyah}

Selain pemikir muda moderat-progresif NU, pemikir muda Muhammadiyah pun telah tumbuh pesat dan menghasilkan wacana kritis. Usaha menerjemahkan kembali ajaran dasar Muhammadiyah, yaitu teologi al-Maun (pemihakan kepada orang miskin) yang dirintis KH. Ahmad Dahlan ${ }^{30}$ — yang sebenarnya adalah pengembangan amal usaha Muhammadiyah agar dapat mengatasi masalah real kehidupan kaum dbuafa (miskin, tertindas)-menjadi perhatian mereka. KH. Ahmad Dahlan dikenal sebagai orang yang menghargai berbagai kelompok agama; beliau juga dikenal sebagai teman di antara para pendeta Kristen dan pastor Katolik. Ini merupakan salah satu indikasi bahwa Dahlan menunjukkan sikap inklusif dan plural. ${ }^{31}$ Sikap inklusif dan plural inilah yang menjadi spirit pemikir muda progresif di lingkungan Muhammadiyah.

\footnotetext{
${ }^{29}$ Nuriyati Samatan, Ibid., h. 252

30 Mohamad Ali, Islam Muda Liberal, Post-Puritan, Post-Tradisional, Opcit., h. 36

${ }^{31}$ Fuad Fachruddin, Agama dan Pendidikan Demokrasi Pengalaman Mubammadiyah dan Nabdlatul Ulama, Opcit., h.112.
} 


\section{NUSANTARA; Journal for Southeast Asian Islamic Studies}

Vol. 15, No. 1, Juni 2019

Di bandingkan pemikir muda NU, gerakangerakan sosial pemikir muda Muhammadiyah ketinggalan dalam merintis LSM. Generasi muda NU telah merintis LSM sudah sejak tahun 1980an, sedangkan fenomena demikian baru muncul di lingkungan Muhammadiyah pada paruh akhir dekade 1990-an. Pada periode kepemimpinan Ahmad Syafii Maarif, sedikitnya ada tiga komunitas intelektual Muhammadiyah yang muncul mewadahi pemikir muda progresif Muhammadiyah, yaitu Pusat Studi Agama dan Peradaban (PSAP), Maarif Institute, dan Jaringan Intelektual Muda Muhammadiyah (JIMM). Munculnya kelompok ini mengawali babak baru perjalanan Muhammadiyah sebagai gerakan intelektual dan pemikiran baru Islam. Gerakangerakan ini awalnya masih terbatas di Jakarta, Yogyakarta dan Malang. Meski masih baru, namun lontaran-lontaran pemikiran kritisnya sudah mampu menarik perhatian publik, khususnya warga Muhammadiyah.

PSAP Muhammadiyah awalnya ditangani oleh Pramono U Tantowi, dan kawan-kawan, merupakan lembaga studi yang meneguhkan komitmen untuk mewujudkan masyarakat demokratis dan berkeadaban yang berbasis pada nilai-nilai keagamaan dan kemanusiaan. Komunitas kedua, Maarif Institute for Culture and Humanity pada mulanya adalah suatu kepanitiaan yang akan mempersiapkan peringatan 70 tahun Ahmad Syafii Maarif dengan menerbitkan sejumlah buku tentang ataupun karya beliau. Tetapi mengingat adanya dinamika kebangsaan yang mengarah pada disintegrasi dan gerakan Islam modernis yang cenderung politis-eksklusif, Maarif Institute terpanggil untuk mencari jalan baru bagi krisis tersebut dengan mengembangkan wacana Muhammadiyah sebagai "tenda bangsa", berupa konsolidasi kekuatan bangsa yang bersifat inklusif dan plural. Pemikir muda yang mengembangkan Maarif Institute sekarang adalah Raja Juli Antoni dan Fajar Riza ul-Haq. ${ }^{32}$

Selain PSAP dan Maarif Institue, dan sekelompok pemikir muda yang kemudian berhimpun dalam Jaringan Intelektual Muda Muhammadiyah (JIMM) telah mendobrak kejumudan atau konservativisme

32 Mohamad Ali, Islam Muda Liberal, Post-Puritan, Post-Tradisional, h. 104-105.
Muhammadiyah ${ }^{33}$ melalui keberanian mereka menafsir ulang al-Qur'an sebagai firman Tuhan yang menjadi gagasan keimanan dalam kehidupan yang berubah secara cepat. ${ }^{34}$

Para pemikir muda progresif Muhammadiyah berkembang untuk suatu tujuan utama, yaitu merajut jejaring dan solidaritas kaum intelektual muda Muslim untuk pencerahan akal budi dan nurani, pembebasan, mewujudkan demokrasi dan transfromasi sosial. Program utama mereka adalah pedagogik kemanusiaan melalui kampanye media, mimbar ilmiah, mimbar jalanan terorganisir; Advokasi intelektual dan gerakan untuk keadilan sosial; Publikasi gagasan dan wacana keislaman yang inklusif, toleran dan berwawasan multikultural; Menggalang jejaring di kalangan intelektual muda Muslim, lintas agama, etnik dan kultural untuk mempersiapkan masa depan kepemimpinan transformatif; dan membangun komunikasi dan relasi dengan berbagai lembaga yang memiliki kepedulian serupa untuk kesepahaman dan kolaborasi demi perubahan sosial berkeadilan dan berkeadaban. ${ }^{35}$ Isu Islam dan demokrasi dalam arti yang luas termasuk salah satu isu yang

${ }^{33}$ Perkembangan yang terjadi di Muhammadiyah ini menarik karena hal ini memang sudah pernah disinyalir oleh Nurcholish Madjid yang mengatakan bahwa Muhammadiyah telah berhenti menjadi organisasi pembaharu, sedangkan rekannya yaitu NU justru telah mengalami pembaruan. Jika Muhammadiyah sekarang meluncur ke arah konservatisme dan fundamentalisme, maka di NU justru mengalami liberalisasi pemikiran. Walaupun tidak bisa dipungkiri bahwa munculnya anakanak muda berhaluan progresif di Muhammadiyah adalah antitesis dari kelompok tua yang berhaluan puritan dan konservatif. Lihat, M. Dawam Rahardjo, "Kata Pengantar" dalam Moh. Shofan, Menegakean Pluralisme Fundamentalisme Konservatif di Muhammadiyah Esai-esai Pemikiran Moh. Shofan dan Refleksi Kritis Kaum Pluralis, dalam proses terbit 2008.

34 Pradana Boy ZTF dan M. Hilmi Faiq (ed), Kembali ke al-Qur'an, Menafsir Makna Zaman (Malang: UMM Press, 2004). Dalam buku ini termuat 19 artikel aktivis JIMM yang menulis mengenai penafsiran baru teologi Islam, dengan pendekatan hermeneutika. Lihat juga "Kata Pengantar" Moeslim Abdurrahman, "Memperebutkan Kebenaran Firman" dalam buku JIMM yang terbaru, Zuly Qodir dkk. (ed.), Mubammadiyah Progresif Manifesto Pemikiran Kaum Muda' (Yogyakarta: Lesfi-JIMM, 2007), h. xxii

35 Ahmad Fuad Fanani, "Jihad Membumikan Pluralisme, Bersatu Menghadang Fundamentalisme" makalah dipresentasikan pada acara Workshop "Pluralisme, Demokrasi dan Civil Society" di Puncak, Bogor, 6-8 Juni 2007. Acara diselenggarakan PSIK Universitas Paramadina. 
Budhy Munawar-Rahman: Masa Depan Wajah Islam Indonesia...

dikembangkan oleh lembaga-lembaga Islam modernis ini.

Menurut Zuly Qodir-salah satu pendiri JIMM - JIMM adalah sebuah paguyuban pemikir muda Muhammadiyah, yang secara resmi kebanyakan sudah tidak lagi menjadi pengurus dalam Muhammadiyah tapi masih sebagai anggota. Mereka memiliki gaya berpikir dan metode penafsiran al-Qur'an yang berbeda dengan mereka yang menjadi pimpinan di tingkat wilayah, daerah, maupun pimpinan pusat. ${ }^{36}$ Perintis JIMM adalah Zuly Qodir, Sukidi Mulyadi, dan Zakiyuddin Baidhawy. Sejak kelahirannya pada Oktober 2003 dengan dukungan oleh Moeslim Abdurrahman dan Ahmad Syafii Maarif, JIMM telah banyak melakukan kegiatan-kegiatan seputar diseminasi Islam, sekularisme, liberalisme dan pluralisme di Indonesia.

Tokoh-tokoh senior Muhammadiyah Moderat-Progresif yang terlibat dalam pengkaderan pemikir muda Muhammadiyah, adalah Ahmad Syafii Maarif, M. Dawam Rahardjo, Moeslim Abdurrahman, M. Amin Abdullah, dan Abd Munir Mulkhan. Merekalah yang banyak memberi inspirasi kepada pemikir muda progresif Muhammadiyah yang mempunyai komitmen kepada gagasan-gagasan sekularisme, liberalisme dan pluralisme, termasuk ide-ide tentang demokrasi, toleransi, hak asasi manusia dan kebebasan beragama. Kehadiran pemikir muda progresif Muhammadiyah ini dapat dibaca sebagai tonggak kebangkitan baru setelah sekian lama Muhammadiyah yang dikenal sebagai gerakan tajdid (pembaruan), hanyut dalam tradisi skriptural-literer. Dengan cara berpikir generasi muda yang memilih jalannya sendiri, yakni jalan liberal-progresif, pemikir muda Muhammadiyah ini-meminjam istilah Moeslim Abdurrahman"akan menuai panggilan sejarahnya sendiri". Menurut Moeslim, Muhammadiyah sekarang membutuhkan satu hal untuk kembali memutar dinamismenya, dan kembali menggapai kemajuan. Harapan itu mungkin saja terjadi jika Muhammadiyah dikendalikan oleh pemikirpemikir muda yang progresif, liberal, dan pluralis ini.

36 Zuly Qodir, Islam Syariah vis a vis Negara, Ideologi Gerakan Politik di Indonesia (Pustaka Pelajar: Yogyakarta, 2007), h. 198.

\section{"Islam Ramah" di Lingkungan Universitas Islam Negeri (UIN) dan Jaringannya (STAIN/IAIN)}

Sebagai institusi pendidikan Islam, posisi Universitas Islam Negeri (UIN) terus mengalamai perubahan. Pada mulanya UIN (dahulu Institut Agama Islam Negeri [IAIN]) dimaknai sebagai lembaga dakwah Islam yang bertanggungjawab menyiarkan agama di masyarakat. Hanya saja, peran sebagai lembaga dakwah akan mengecilkan peran yang lebih besar, yaitu sebagai lembaga pendidikan Islam, di mana UIN dituntut bertanggungjawab secara akademis-ilmiah.

Beragamanya pendekatan dalam studi agama di UIN memberikan gambaran yang cukup jelas betapa dinamisnya pemikiran keislaman di perguruan tinggi Islam terbesar di Indonesia ini. Pemikiran inilah yang mendorong adanya gagasan tentang pengembangan UIN-khususnya Jakarta dan Yogyakarta—sebagai pilot project Universitas Islam Negeri (UIN), di bawah Departemen Agama Republik Indonesia yang mencakup bukan hanya fakultas-fakultas agama, tetapi juga fakultas-fakultas umum dengan corak epistemologi keilmuan dan etika moral keagamaan yang integralistik. ${ }^{37}$

Secara umum, kekuatan kedua UIN Jakarta dan Yogyakarta bisa dilihat dalam beberapa hal: pertama, pengembangan institusi; kedua, kualitas tenaga pengajar; ketiga, tingkat partisipasi dalam penyebaran gagasan-gagasan baru; keempat, pengembangan kurikulum, dan; kelima, metodologi. ${ }^{38}$

Salah satu kekuatan intelektual UIN adalah menghasilkan ratusan lulusan S3 yang diharapkan akan ikut mempengaruhi wajah Islam Indonesia menjadi lebih progresif. Seluruh kegiatan intelektual di UIN ini diarahkan untuk mengubah mentalitas umat, mempersiapkan umat Islam memasuki era industrialisasi, globalisasi dan perdagangan bebas. Melalui diseminasi lewat penerbitan, seminar, training-training, dan berbagai pengembangan gagasan lewat lembagalembaga studi yang dibangun di bawah UIN,

37 M. Amin Abdullah, Islamic Studies di Perguruan Tinggi Pendekatan Integratif-Interkonektif (Yogyakarta: Pustaka Pelajar, 2006), h. 99

${ }^{38}$ Fuad Jabali dan Jamhari, LAIN, Modernisasi Islam di Indonesia (Jakarta: Logos, 2002), h. 28 
diharapkan wajah Islam yang progresif itu betulbetul terwujud-dan ini sudah dibuktikan dengan pentingnya peranan STAIN dan IAIN di seluruh Indonesia yang berjumlah lebih dari 60 kampus. ${ }^{39}$

Figur Harun Nasution, bagi UIN Jakarta mempunyai posisi yang sangat penting. Bukan saja ia pernah menjadi Rektor untuk dua periode dan kemudian menjadi Direktur Pascasarjana selama beberapa periode. Harun telah menulis sejumlah buku teks bagi seluruh mahasiswa STAIN/IAIN seluruh Indonesia yang telah mempengaruhi cara berpikir mahasiswa menjadi lebih progresif. Harun berpendapat bahwa pengajaran Islam di IAIN masih terbatas hanya pada pengajaran agama yang fiqh oriented. Di samping itu, pengajaran agama, baik, tasawuf, maupun sejarah terbatas pada pemikiran tokohtokoh tertentu saja. Karena itu harus memasukkan mata kuliah, tasawuf, ilmu kalam, tauhid, sosiologi, dan metodologi riset dalam kurikulum baru. ${ }^{40}$

Pemahaman Islam yang demikian itu, menurut Harun hanya akan menghasilkan mahasiswa yang mempunyai pikiran parsial, dan hanya melihat Islam secara sempit saja. Oleh karena itu Harun mengusulkan untuk membuat suatu buku teks yang melihat Islam secara pluralis, sekaligus komprehensif. Usul Harun untuk pengenalan Islam secara pluralis dan komprehensif, direalisir lewat 2 jilid bukunya Islam ditinjau dari Berbagai Aspeknya yang kemudian diintegrasikan ke dalam kurikulum nasional untuk pengajaran Islam. ${ }^{41}$ Yang harus dihasilkan oleh IAIN, menurut Harun, haruslah sarjana Muslim dan ulama yang ilmu pengetahuannya bukan hanya terbatas pada pengetahuan agama saja tetapi juga mencakup apa yang lazim disebut pengetahuan umum, dan juga mencakup akhlak dan budi pekerti yang luhur. ${ }^{42}$

Harun Nasution sempat menjadi Rektor IAIN Ciputat Jakarta selama dua pereode (19741982). Salah satu jasanya yang sekarang telah membuahkan hasil adalah munculnya banyak

39 Kuntowijoyo, Muslim Tanpa Masjid Esai-esai Agama, Budaya, dan Politik dalam Bingkai Strukturalisme Transendental (Bandung: Mizan, 2001), h. 111

${ }^{40}$ Fuad Jabali dan Jamhari, Opcit., h. 42

${ }^{41}$ Ibid., h. 43

${ }^{42}$ Harun Nasution, Islam Rasional Gagasan dan Pemikiran(Bandung: Mizan, 1995), h. 391 intelektual Islam Moderat-Progresif adalah langkahnya bersama mantan Menteri Agama Munawir Sjadzali, mengusahakan berdirinya Fakultas Pascasarjana di IAIN pada 1982. Harun mendesak pentingnya Fakultas Pascasarjana ini, karena menurutnya organisasi massa Islam yang ada belum mampu menciptakan pemimpin umat masa depan yang rasional, mengerti Islam secara komprehensif, tahu tentang ilmu agama dan menguasai. Menurutnya, sangat penting untuk mengetahui pengertian ilmu secara umum, dan menjadi progresif. ${ }^{43}$

Harun Nasution juga dikenal sebagai tokoh yang mendorong pengiriman mahasiswa Islam meneruskan kuliahnya di berbagai Universitas di luar negeri, baik ke Timur Tengah maupun ke Barat-yang menjadikan mereka lebih progresif. Pembaruan Harun yang terakhir yang kini menjadi perhatian banyak orang adalah idenya untuk mengubah IAIN menjadi Universitas. Ide perubahan IAIN itu dimaksudkan untuk mengembalikannya apresiasi intelektual Muslim kepada ilmu pengetahuan dan. Ia menegaskan,

"Yang diperlukan umat di zaman sekarang ini bukan hanya sarjana-sarjana yang mengetahui ilmu agama saja, tapi juga ilmu umum. Harus diakui, tidak banyak orang yang bisa menguasai dua-duanya secara mumpuni. Hanya orang-orang yang jenius saja yang bisa melakukannya. Tapi prinsipnya, kita berupaya untuk mencetak sarjana-sarjana agama yang tidak asing pada ilmu-ilmu umum.... Sejarah membuktikan, sarjana-sarjana Musim di masa lampau mampu menguasai ilmu-ilmu agama sekaligus ilmu-ilmu umum, bahkan menguasai ....inilah dasar pemikiran kita sehingga ada keinginan untuk mengubah IAIN menjadi UIN.,"44

Senada dengan Harun Nasution, Azyumardi Azra, dalam sebuah wawancara di Jawa Pos, mengatakan, "bahwa dalam konteks sekarang, yang diajarkan [di UIN] tidak hanya

43 “Gebrakan Harun Nasution", Republika, Jumat, 5 Januari 1996. Lihat juga, Kusmana (Ed.), Proses Perubahan IAIN Menjadi UIN Syarif Hidayatullah Jakarta, Rekaman Media Massa (Jakarta: UIN Jakarta Press, 2002), h. 15-16.

44 Prof. Dr. Harun Nasution "Sudah Saatnya IAIN Diubah Menjadi Universitas", Republika 5 Januari 1996. Lihat juga, Kusmana (Ed.), Ibid., h. 3-4. 
dogma-dogma ritual yang bersifat fiqh oriented, tapi juga wawasan-wawasan keislaman yang lain, termasuk misalnya wawasan Islam mengenai kemodernan, kemajuan ilmu pengetahuan dan kebangsaan....paradigma pendidikan islam adalah integrasi keislaman, keindonesiaan dan kemanusiaan." 45

Untuk mengintegrasikan spirit keislaman, keilmuan dan keindonesiaan menurut Komaruddin Hidayat, hendaknya didemonstrasikan lagi oleh perguruan-perguruan tinggi seperti UIN, dalam arti lebih menggali cita-citanya. Namun demikian, lanjutnya, karena upaya tersebut masih dalam proses, maka hasilnya pun harus terus mengalami koreksi atau pembenahan. Artinya, belum bisa kita menghakiminya, sebaliknya justru yang diperlukan menurutnya, adalah keterlibatan semua pihak untuk bersamasama mendorong proses integrasi [keislaman, keilmuan, dan keindonesiaan] tersebut. ${ }^{46}$

Namun, Komaruddin Hidayat sendiri menyadari bahwa, UIN hanyalah salah satu scope kecil dalam mozaik besar dunia Islam Indonesia, sehingga perannya jangan terlampau dibesarbesarkan dan tidak mungkin dituntut untuk dapat mengatasi segenap persoalan yang ada. Namun demikian, hendaknya masing-masing institusi yang mengaku Islam, baik partai politik, ormas, pesantren, STAIN, IAIN, dan UIN, maupun LSM masing-masing mengembangkan jati dirinya yang akomodatif atau "santun" terhadap keanekaan. Lebih jauh, dia mengatakan, bahwa dirinya sebagai Rektor UIN sekarang ini akan menjadikan UIN Syarif Hidayatullah Jakarta sebagai pintu gerbang dunia untuk melihat Islam Indonesia, dengan segala isunya. Hal ini, menurutnya sudah dilakukan melalui kerjasama dengan berbagai perguruan tinggi asing.

Dari pernyataan Komaruddin Hidayat, tampak bahwa UIN mempunyai komitmen untuk merumuskan ilmu-ilmu yang akomodatif terhadap berbagai isu Islam kontemporer, seperti sekularisme, liberalisme dan pluralisme. Menurut Komar, yang disebut kebenaran itu tidaklah selalu tunggal. Karena itu, dirinya melihat pengertian sekularisme, pluralisme dan liberalisme sebagai

45 "Keislaman, Kemanusiaan dan Keindonesiaan" Jawa Pos, Minggu 28 Januari 2002. lihat juga, Kusmana (Ed.), Ibid., h. 167

46 Wawancara dengan Komaruddin Hidayat. alasan sosiologis bahwa realitas keberagamaan itu sangat beragam, dan perlunya sikap saling menghargai atau toleransi aktif. Dia mengatakan:

"Kalau pluralisme dipahami sebagai cerminan atas realitas sosial, maka itu adalah kemestian. Kita hidup dalam dunia yang begitu majemuk, sehingga sulit bagi kita untuk tidak bergaul dengan kelompok yang berbeda. Pluralitas itu sesungguhnya paling mudah terjadi dalam dunia science dan kebudayaan. Dalam dunia science kita tidak bisa untuk tidak menghargai perbedaan argumentasi. Dalam wilayah budaya, contoh yang paling mudah kita dapatkan pada bangunan dan arsitektur masjid. Unsur dalam bangunan masjid yang mana yang murni Islam? Menara sebenarnya berasal dari tradisi Majusi, begitu pula kubah. Speaker dahulu di Arab tidak ada. Lalu apanya yang khas Islam? Yang pasti tata cara ibadahnya itu sendiri." 47

Senada dengan Komar-dan ini sudah menjadi tradisi penerimaan pluralisme di UIN sejak lama-Harun Nasution, seniornya di IAIN, mengatakan bahwa Islam sebagai salah satu agama semitik, mengajarkan sikap toleran terhadap agama-agama monoteis lain, terutama agama Yahudi dan Kristen. Dengan kedua agama ini Islam mempunyai hubungan yang erat. Islam, menurutnya, mengakui bahwa kedua agama ini berasal dari satu sumber, yaitu Tuhan Yang Mahaesa. Ajaran dasar yang disampaikan kepada nabi-nabi yang ada dalam agama Yahudi dan yang disampaikan kepada Yesus adalah sama dengan ajaran dasar yang disampaiakan kepada Nabi Muhammad. Ajaran dasar yang dimaksud adalah percaya kepada Tuhan Yang Mahaesa dan menyerahkan diri kepada-Nya. ${ }^{48}$

\section{${ }^{47}$ Ibid.}

48 Menurut Harun Nasution, sifat muttaqin dan shalibin dalam arti orang yang patuh pada Tuhan dan yang akan masuk surga juga diberikan oleh al-Qur'an kepada orang bukan Islam. Ayat 112, 113, dan 114 surah Ali 'Imran mengatakan bahwa sebagian ahli Kitab, yaitu pemelukpemeluk agama Yahudi dan Kristen, percaya kepada Tuhan Yang Maha Esa, senantiasa dekat kepada Tuhan, senantiasa berbuat baik dan menjauhi perbuatan-perbuatan jahat. Ahli Kitab serupa ini, oleh ayat-ayat itu, diberi sifat muttaqin dan shalibin. Jadi, sifat ini bukan hanya untuk umat Islam. Lihat, Harun Nasution, Islam Rasional Gagasan dan Pemikiran, h.272. Harun juga menekankan kenyataan bahwa doktrin- 
Bagi Komar, teologi pluralis sangat kuat pada ajaran Hindu dan Buddha-yang lebih tepat disebut sebagai way of life, daripada agama. Agamaagama perlu belajar dari pluralisme ini.

"Hindu dan Buddha memandang
beragam agama bagaikan beragam sungai
yang kesemuanya tengah mengalir menuju
lautan. Hanya saja ketika seseorang
tengah berada di sebuah sungai, seolah-
olah sungai hanyalah satu dan unik, pasti
berbeda dari yang lain. Entah
kedalamannya, tebingnya, ikan-ikannya,
dan sebagainya. Tetapi kalau kita
melihatnya dari langit, ternyata banyak
sekali sungai dan semuanya menuju ke
lautan. Begitulah halnya dengan beragam
agama, mereka memandangnya semua
menuju pada muara yang sama. Ada lagi
yang menggunakan ibarat cahaya di dalam
rumah. Mata kita hanya melihat cahaya
sebatas yang ada di dalam rumah kita.
Padahal, dari matahari yang sama dan
satu, sekian banyak rumah, kebun dan
daerah juga memperoleh cahayanya." 49

Komar menegaskan bahwa memandang pembaruan teologi agar lebih inklusif dan pluralis itu sia-sia dan tidak berguna sama sekali-seperti sering diungkapkan oleh kolega-koleganya yang eksklusif-adalah hal yang keliru. Walaupun Komar menyadari bahwa teologi memang bisa membawa pada eksklusivisme. Dan ekslusivisme itu tidak bisa diabaikan. Pasalnya, ekslusivisme merupakan watak setiap manusia karena manusia begitu gampang mengikatkan dirinya kuat-kuat pada jenis ikatan tertentu, tidak hanya dalam teologi an sich. Ekslusivisme, demikian Komar, akan menjadi semakin militan ketika memperoleh

doktrin Islam berwajah dua: yang mutlak (qath' $)$ dan yang relatif (zhanni). Ia menegaskan bahwa 95\% dari ajaranajaran Islam adalah produk penafsiran manusia, dan hanya $5 \%$ yang murni berasal dari al-Qur'an. Dalam pandangannya, pembaharuan keagamaan dalam Islam pada dasarnya adalah upaya untuk menafsirkan kembali komponen-komponen yang zhanni dalam ajaran-ajaran Islam sejalan dengan kebutuhan situasi yang telah berubah. Lihat, Bahtiar Effendy, Islam dan Negara Transformasi Pemikiran dan Praktik Politik Islam di Indonesia Jakarta: Paramadina, 1998), h. 146

${ }^{49}$ Wawancara dengan Komaruddin Hidayat, Jakarta, penegasan dari paham agama yang diyakininya, seperti halnya para teroris yang yakin sekali meledakkan bom itu merupakan tindakan suci. Karena hal itu, merupakan fenomena kultural, antropologis, psikologis yang kebetulan mendapat penguatan dari agama. ${ }^{50}$

Oleh karenanya, lanjut Komar, pengertian sekularisme mesti dipahami dalam konteks sosiologis - yakni suatu paham yang mendorong bahwa kehidupan bernegara dan ranah politik hendaknya didekati secara rasional dengan teoriteori politik modern, di mana agama berada pada tataran moral; dalam proses teknis politis sudah melewati mekanisme demokrasi; lantas masalahmasalah dunia didekati dengan ilmu dan teknologi. Dalam pengertian seperti ini sesungguhnya sekularisme bisa diterima. ${ }^{51}$

Sebagai [mantan] Rektor UIN, Komar, berpendapat bahwa tidak ada yang perlu ditakutkan dengan penerimaan mahasiswa nonMuslim, mengingat UIN bukanlah lembaga konspirasi, tetapi lembaga pendidikan dan peradaban. Kalau orang lain masuk ke UIN, papar Komar, berarti orang tersebut tertarik pada ilmu keislaman. Karenanya sebagai pribadi dia setuju apabila UIN membuka diri dan mempersilahkan umat lain menimba ilmu di kampus ini. Komar, percaya bahwa Islam dan kampus ini merupakan sumber ilmu dan kebenaran. $^{52}$

Perkembangan keilmuan-akademis di lingkungan UIN Yogyakarta, juga menarik untuk dicermati. Bergulirnya wacana keislaman yang bersifat kritis-hermeneutis dan histories-empirik, tidak bisa dilepaskan dari peran Mukti Ali. Mukti Ali pernah menjabat sebagai Rektor dan Direktur Pascasarjana UIN (dahulu IAIN) Yogyakarta. Mukti Ali, pada saat menjabat sebagai Menteri Agama RI mendukung gagasan Harun Nasution, untuk memberikan pengajaran tentang pengenalan Islam yang ditinjau dari berbagai aspeknya, seperti yang telah disinggung di atas. Jika Mukti Ali lebih menonjol pada sikap pribadi dan sikap akademis, maka pengaruh Harun, 2007. 
Budhy Munawar-Rahman: Masa Depan Wajah Islam Indonesia...

terlihat pada keberanian mengemukakan pendapat yang kontroversial. ${ }^{53}$

Belajar perbandingan agama dan ilmu agama-agama (religious studies) di UIN dapat dikatakan sebagai obsesi dari Mukti Ali untuk membangkitkan dialog antar agama demi menghilangkan kecurigaan. Pengetahuan tentang agama lain menurut Mukti Ali akan lebih meningkatkan toleransi terhadap perbedaan agama. ${ }^{54}$ Agaknya Harun dan Mukti Ali mempunyai pandangan pluralisme yang sama, yakni menumbuhkan sikap terbuka terhadap perbedaan, termasuk di dalamnya adalah perbedaan agama. ${ }^{55}$ Sejalan dengan Mukti Ali, M. Amin Abdullah-yang sering dijuluki rekan sejawatnya sebagai "Bapak Hermeneutika" di IAIN se-Indonesia, dan (mantan) Rektor UIN Yogyakarta, mengatakan bahwa sesungguhnya problem yang akut dalam ilmu-ilmu keislaman merupakan tema sentral dalam pembahasan akademik pada domain ilmu.

Oleh karena itu, menurut Amin, mempertahankan, menjaga, mengkritisi, menguji ulang, mencermati, memperbaiki dan mengolah kembali teori-teori ilmiah adalah merupakan tugas utama seseorang yang bergerak di bidang riset dan pengembangan di lapangan ilmu pengetahuan apapun. ${ }^{56}$ Karenanya, dalam pandangan Amin, Perguruan Tinggi Agama khususnya STAIN/IAIN/UIN, secara sadar harus berani mengkaji ulang visi, misi dan paradigma keilmuan yang pernah dibangunnya selama 50-an tahun. Bangunan ilmu pengetahuan yang dikotomik antara ilmu pengetahuan umum dan ilmu

\footnotetext{
${ }^{53}$ Fuad Jabali dan Jamhari, LAIN Modernisasi Islam di Indonesia, h. 46.

54 Pada 1971 pemerintah mengangkat Prof. Dr. A. Mukti Ali sebagai Menteri Agama (1971-1978) menggantikan pendahulunya K.H.M. Dachlan. Mukti Ali tamatan Universitas McGill, Montreal, Kanada, dikenal sebagai guru besar yang ahli dalam ilmu perbandingan agama. Tampaknya dia sangat dibutuhkan untuk menata hubungan antar umat beragama di Tanah Air di saat-saat isu agama menjadi sangat peka. Ibid., h. 78. untuk mengetahui pemikiran Mukti Ali mengenai perbandingan agama, baca, Mukti Ali, Ilmu Perbandingan Agama (Yogyakarta: IAIN Sunan Kalijaga Press, 1988). Buku ini diterbitkan dalam rangka memperingati 25 tahun Ilmu Perbandingan Agama di IAIN.

55 Ibid.h, 46.

56 M. Amin Abdullah, "Islamic Studies di Perguruan Tinggi Pendekatan Integratif-Interkonektif” h. 40-41.
}

pengetahuan agama harus diubah menjadi bangunan keilmuan baru yang lebih holistikintegralistik atau paling tidak bersifat komplementer.

Tujuan STAIN/IAIN/UIN, papar Amin, perlu diorientasikan pada lahirnya sarjana yang memiliki tiga kemampuan sekaligus, yaitu kemampuan menganalisa secara akademik, kemampuan melakukan inovasi, dan kemampuan memimpin sesuai denagn tuntutan persoalan kemasyarakatan, keilmuan, maupun profesi yang ditekuninya dalam satu tarikan nafas etos keilmuan dan keagamaan. ${ }^{57}$ Pemikiran inilah yang mendorong adanya gagasan tentang pengembangan IAIN sebagai pilot project menjadi Universitas Islam Negeri (UIN), di bawah Departemen Agama Republik Indonesia yang mencakup bukan hanya fakultas-fakultas Agama, tetapi juga fakultas-fakultas umum dengan corak epistemologi keilmuan dan etika moral keagamaan yang integralistik. ${ }^{58}$

Amin menegaskan,

"IAIN di era global ini, dapat diperkuat dengan tenaga pengajar dan dosendosennya dengan berbagai metode dan pendekatan baru dalam Islamic studies, bumanities, dan ilmu-ilmu sosial, sedangkan dalam fakultas-fakultas umum perlu dibekali muatan-muatan spiritual dan moral keagamaan yang lebih kritis dan terarah dalam format integrated curriculum, dan bukannya separated curriculum seperti yang berjalan selama ini". Pengembangan IAIN ini diharapkan melahirkan pendidikan Islam yang ideal di masa depan. Program reintegrasi epistemologi keilmuan dan implikasinya dalam proses belajar mengajar secara akademik pada gilirannya akan menghilangkan dikotomi antara ilmu-ilmu umum dan ilmu-ilmu agama seperti yang telah berjalan selama ini". ${ }^{59}$

Kegelisahan Amin, di atas, sangat beralasan mengingat, kesenjangan wawasan keilmuan selama ini cukup berakibat pada dinamika keilmuan dan implikasinya dalam kehidupan sosial keagamaan dalam masyarakat Indonesia,

\footnotetext{
57 Ibid., h. 97-98.

58 Ibid., h. 99.

${ }^{59}$ Ibid., h. 100.
} 
mengingat alumni UIN sudah banyak yang menjadi tokoh di masyarakat di manapun mereka berada. ${ }^{60}$ Seluruh disiplin keilmuan, seperti Islamic studies, (fikih, ilmu kalam, tasawuf, dll), yang berkembang di UIN menurut Amin, sangat membutuhkan dan memerlukan pemahaman tentang bumanities (ilmu-ilmu kemanusiaan) kontemporer, karena ini merupakan ilmu-ilmu baru yang menjadi kelanjutan dari Islamic studies. Humanities, social dan natural sciences merupakan cara pandang orang yang hidup di zaman sekarang. ${ }^{61}$

Dari sinilah, lanjut Amin, memahami sekularisasi, dalam pengertian proses, sangat terkait dengan the idea of progress dan, terutama, kemajuan pendidikan, the rise of education, bukan lagi negara. Negara hanya sebagai fasilitator. Mustahil negara menjadi besar sementara rakyatnya bodoh tak berpendidikan yang baik. Yang terpenting rakyatnya harus diberi pendidikan yang memadai, terlebih lagi di era modern seperti sekarang ini. Modernisasi sangat terkait dengan pendidikan. Kalau pendidikannya tidak bergerak, maka sekularisasi juga otomatis akan sulit berkembang. ${ }^{62}$

Di lingkungan IAIN sendiri, ilmu-ilmu keislaman yang diajarkan ditempatkan sebagai subyek kajian akademik dan ilmiah. Ilmu-ilmu keislaman tidak ditempatkan di dalam ruang hampa sejarah, sebagai doktrin yang semata-mata harus diyakini dan diterima tanpa pertimbangan dan sikap kritis. Pelbagai khazanah ilmu pengetahuan Islam ditempatkan di dalam konteksnya sendiri yang bisa diamati dan dianalisa secara ilmiah. Oleh sebab itu, UIN tidak menutup diri dengan menawarkan khazanah pemikiran Islam dari satu madzhab tertentu, melainkan dipelajari dan dianalisa karakteristiknya masingmasing secara terbuka. Harapan yang dikemukakan Amin, diamini oleh Azyumardi Azra, mantan Rektor UIN Jakarta, bahkan ia

60 M. Amin Abdullah, "Muhammad Arkoun: Perintis Penerapan Teori Ilmu-ilmu Sosial Era PostPositivis dalam Studi Pemikiran Keislaman", dalam Mohammad Arkoun, Membongkar Wacana Hegemonik dalam Islam dan Post Modernisme (Surabaya: Al-Fikr, 1992).

2007.

${ }^{61}$ Wawancara dengan M. Amin Abdullah, Maret

62 Ibid menyebut "model pendidikan Islam yang dikembangkan di IAIN adalah "Islam liberal". 63

Untuk mengetahui pikiran-pikiran Azyumardi lebih jauh mengenai eksistensi IAIN, sebagai lembaga akademik-yang mengembangkan pemikiran Islam seperti Islam Indonesia, termasuk di dalamnya demokrasi dan hak asasi manusia, berikut kutipannya:

"Sebagai lembaga akademik, kendati IAIN terbatas memberikan pendidikan Islam kepada mahasiswanya, tetapi Islam yang diajarkan adalah Islam yang liberal. IAIN tidak mengajarkan fanatisme mazhab atau tokoh Islam, melainkan mengkaji semua mazhab dan tokoh Islam tersebut dengan kerangka, perspektif dan metodologi modern. Untuk menunjang itu, mahasiswa IAIN pun diajak mengkaji agama-agama lain selain Islam secara fair, terbuka dan tanpa prasangka. Ilmu perbandingan agama menjadi mata kuliah pokok mahasiswa IAIN". ${ }^{64}$

Model studi Islam seperti yang dikatakannya, di atas, menurut Azyumardi akan dapat membuka wawasan mahasiswa STAIN/IAIN/UIN yang pada umumnya berbasis pesantren dan madrasah. Karena itu, dalam pengamatan Azyumardi, "liberalisasi" studi Islam di STAIN/IAIN/UIN telah mengubah cara pandang mahasiswa umumnya terhadap ilmu. Di STAIN/IAIN/UIN, mereka bisa memahami bahwa belajar sosiologi, antropologi, sejarah, psikologi sama pentingnya dengan belajar tafsir al-Qur'an. Bahkan menurutnya, ilmu itu bisa berguna untuk memperkaya pemahaman mereka tentang tafsir. ${ }^{65}$

Model studi Islam dengan pendekatan liberal yang dikembangkan oleh STAIN/IAIN/UIN, terasa sangat tampak berpengaruh di pondok pesantren. Indikasi itu misalnya, bisa dilihat di pesantren atau madrasah Darussalam, Sumedang, Jawa Barat. Model pendidikan yang dikembangkan oleh kyai maupun ustadz-ustadznya yang note bene lulusan UIN berbeda dengan metode konvensional yang

${ }^{63}$ Fuad Jabali dan Jamhari, LAIN, Modernisasi Islam di Indonesia, h. 116-117

${ }^{64}$ Ibid, h. 117

${ }^{65}$ Ibid, h. 117 
Budhy Munawar-Rahman: Masa Depan Wajah Islam Indonesia...

dikembangkan di pesantren-pesantren pada umumnya. Alumni UIN tidak kaku dalam menafsirkan teks-teks al-Qur'an maupun Hadits. Selain itu, menurut pimpinan pesantren tersebut, Syamsul Falah, seorang kyai PERSIS (Persatuan Islam), ustadz-ustadz alumni UIN tersebut memberikan nuansa liberal dalam pengajaran Islam. $^{66}$

Kenyataan ini membuktikan bahwa pengaruh UIN terhadap transformasi dan modernisasi pemahaman terhadap ilmu-ilmu keislaman di pesantren bisa diterima dengan baik. Metode kajian Islam dengan menggunakan perspektif modern yang diajarkan di UIN mampu mendorong pesantren dari yang semula tertutup dan apatis terhadap gagasan kemajuan, kini ada kecenderungan untuk mau berubah dan terbuka terhadap realitas masyarakat secara kontekstual. Dengan adanya pengaruh pendidikan yang diajarkan UIN, banyak pesantren yang menyelenggarakan aktifitas ekonomi dan pembangunan masyarakat pedesaan maupun pendirian sekolah-sekolah atau madrasah formal, yang terjadi sejak tahun 1970-an. ${ }^{67}$

Sebagaimana Azyumardi, Amin juga memaparkan bahwa pendidikan yang lebih menekankan pada sisi teologis an sich, akan berakibat pada tingginya al-aql al-labuti, nalar yang ketuhanan; bukan lebih mengeksplorasi al-aqlu alfalsafi, al-aqlu al-ilmi atau al-aqlu al-tarikhi (dimensi dan sudut antropologis dari pemikiran tentang ketuhanan). Padahal nalar ketuhanan, lanjut Amin, jika tidak ekstra hati-hati, dapat berubah memasuki wilayah klaim absoluditas, permulaan sikap otoriter dalam pemikiran keagamaan. ${ }^{68}$ Amin tidak setuju membiarkan entitas yang relatif terlepas atau terpisah dengan yang absolut. Begitu juga, yang "absolut" terlepas dari yang relatif. Singkatnya di dalam absoluditas ada relativitas; dan di dalam relativitas terselip absoluditas. ${ }^{69}$ Agama, lanjut Amin, selain mengurusi urusan domestik, ia juga mengurusi wilayah publik.

Karenanya, fatwa-fatwa yang dikeluarkan oleh institusi keagamaan seperti MUI, dalam pandangannya, perlu mempertimbangkan secara

\footnotetext{
${ }^{66}$ Ibid., h. 118

${ }^{67}$ Ibid., h. 119.

${ }^{68}$ Wawancara dengan M. Amin Abdullah, Maret

${ }^{69}$ Ibid.
} 2007. cermat karakteristik kedua wilayah yang berbeda tetapi berkait-kelindan. ${ }^{70}$ Sebagai seorang penganut legal pluralism, Amin tidak berkeberatan terhadap usaha untuk melegal-formalkan syariat Islam karena itu merupakan hak bagi siapapun. Namun, baginya, yang harus ditekankan di sini adalah kesadaran yang dapat mengayomi, bukan malah memonopoli, yang harus dimiliki oleh para tokoh agama. Untuk menjaga stabilitas segenap warga negara, demikian Amin, maka tetap memberi tempat buat organisasi-organisasi agama atau kefatwaan, tetapi dengan disertai pembekalan bagi tokoh-tokohnya lewat agenda peningkatan kualitas pendidikan. "kita mesti menggali ulang bagaimana nation-state Indonesia itu mendukung konsensus legal pluralism dengan ide nasionalisme. Seperti apa materi dialognya dan bagaimana in praxis-nya legal pluralism dengan the idea of nationstate sehingga kemudian disebut dengan suatu hukum Indonesia" ujarnya. ${ }^{71}$

Kebijakan-kebijakan pemerintah atau Departemen Agama memang tidak secara ekspilisit memperlihatkan peran dan sumbangan alumni UIN. Kebijakan-kebijakan itu memang muncul pada tingkat Menteri Agama. Meskipun demikian, dapat dipastikan peran dan sumbangan para birokrat dan pengambil kebijakan di tingkat Dirjen dan Direktur Departemen Agama. Tanpa sumbangan mereka peraturan menteri itu bukan hanya tidak pernah terwujud, tetapi bahkan tidak terlaksana pada tingkat implementasinya. ${ }^{72}$

Sebagaimana diketahui, bahwa pada masa kepemimpinan Munawir Sjadzali, Departemen Agama menaruh perhatian besar terhadap pembinaan kerukunan hidup umat beragama. Menurut Munawir, kerukunan hidup umat beragama di Indonesia bukan lagi merupakan suatu pilihan, tetapi sudah merupakan suatu keharusan. ${ }^{73}$ Diakui sendiri oleh Munawir, bahwa persinggungan anak-anak lulusan IAIN dengan dunia perguruan tinggi Barat akan dapat memperluas cakrawala ilmiah mereka, serta

${ }^{70}$ M. Amin Abdullah MUI, "Fatwa dan Otoritas Keagamaan di Indonesia" dalam Ahmad Suaedy dan Rumadi, Kala Fatwa Jadi Penjara (Jakarta: The Wahid Institute, 2006), h. 48.

${ }^{71}$ Wawancara dengan M. Amin Abdullah, Maret 2007.

${ }^{72}$ Fuad Jabali dan Jamhari, IAIN Modernisasi Islam di Indonesia, h. 90.

${ }^{73}$ Ibid. h. 88. 
belajar berpikir kritis terhadap ilmu pengetahuan, termasuk pengetahuan agama. Dia mencontohkan Prof. Dr. Mukti Ali dan Prof. Dr. Harun Nasution sebagai ilmuwan yang mampu membawa Islam ke dalam pemahaman modern dan sanggup membawa juru bicara Islam di Indonesia ke dunia luar. ${ }^{74}$

Dalam sebuah dialog dengan Presiden Soeharto, Munawir menyampaikan pemikirannya, "Bapak Presiden, selama umat Islam berpendirian bahwa ayat al-Qur'an itu final dan harus diartikan secara harfiah, maka Islam akan merupakan kendala bagi kemajuan dan pembangunan... [P]emahaman kita terhadap al-Qur'an harus kontekstual." Mendengar itu, Presiden Soeharto justru mengatakan, bahwa gagasan Munawir itu tidak salah, justru strategis dan perlu. Bahkan, Presiden Soeharto menyarankan agar Munawir tidak sendirian, dan disarankan menggunakan IAIN untuk mencetak ilmuwan-ilmuwan yang bisa mengikuti pemahaman yang kontekstual. ${ }^{75}$ Dari proses inilah apresiasi paham sekularisme, liberalisme dan pluralisme berkembang pada kalangan intelektual Islam Moderat-Progresif di STAIN/IAIN/UIN seluruh Indonesia.

Sebagai penutup uraian tentang diseminasi gagasan sekularisme, liberalisme dan pluralisme di UIN ini menarik memperhatikan apa yang dikemukakan oleh M. Nur Kholis Setiawan, pengajar UIN Yogyakarta, seorang intelektual muda penggagas Islam Moderat-Progresif terkini, bahwa

${ }^{74}$ Elza Peldi taher (ed) Kontekstualisasi Ajaran Islam 70 Tabun Prof. Dr. H. Munawir Sjadzali (Jakarta: Paramadina, 1995), h. 83.

75 Ibid., h. 97. Sebagai mantan Menteri Agama, baik Munawir Sadjazli maupun Tarmidzi Taher, keduanya samasama ditempatkan di garis depan dalam konteks membangun kerukunan antar umat beragama.

Sebagaimana pendahulunya, Tarmidzi Taher, juga selalu menekankan pentingnya kerukunan antar umat beragama. Dalam berbagai pidatonya di forum-forum nasional dan internasional, Tarmidzi Taher, selalu menyerukan perlunya digalang keharmonisan antarumat beragama di Indonesia di bawah naungan ideologi negara Pancasila. Kini, melalui Center for Moderate Moslem (CMM) yang dipimpim Tarmidzi Taher, membentuk strategi dakwah-yang dikenal dengan 'Islam Madzhab Tengah'-di tengah kerasnya tarik menarik gerakan Islam radikal dan gerakan Islam liberal. Lihat, Herry Sucipto (ed.), Islam Madzhab Tengah, Persembahan 70 Tahun Tarmidzi Taher (Jakarta: Grafindo, 2007), h. 17.
"Islam Moderat-Progresif adalah Islam yang menawarkan sebuah kontekstualisasi penafsiran Islam yang terbuka, ramah, segar, serta responsif terhadap persoalanpersoalan kemanusiaan. Hal ini ...berbeda dengan Islam militan dan ekstrim [dalam tulisan ini disebut "Islam Radikal"] yang tetap berusaha menghadirkan wacana penafsiran masa lalu serta menutup diri terhadap ide-ide baru yang berasal dari kelompoknya. Bahkan, seringkali untuk meneguhkan keyakinannya, mereka bertindak dengan mengklaim diri sebagai pemilik otoritas kebenaran untuk bertindak secara otoriter terhadap paham dan agama lain...[1]slam Progresif menawarkan sebuah metode berislam yang menekankan terciptanya keadilan sosial, kesetaraan gender, dan pluralisme keagamaan". ${ }^{76}$

\section{Masa Depan Wajah "Islam Ramah" Indonesia}

Di atas sudah dianalisis bagaimana pengarusutamaan dan diseminasi ide-ide Islam dan demokrasi pada lembaga-lembaga Islam Moderat-Progresif di Indonesia yang berbasiskan "tradisional" Islam (diantaranya berafiliasi dengan NU) dan lembaga-lembaga berbasiskan "modernis" (diantaranya berafiliasi Muhammadiyah) dan jaringan STAIN/IAIN/UIN se-Indonesia, yang merupakan gabungan para pemikir Muslim Progresif dari latarbelakang "tradisional" (seperti NU) maupun "modernis" (seperti Muhammadiyah).

Analisis di atas menunjukkan bahwa pengarusutamaan dan diseminasi ide-ide Islam dan demokrasi bukan sekadar berhenti pada tataran diskursus tetapi lebih dari itu mereka telah mampu mengimplementasikannya secara empiris dengan tujuan memberikan pemahaman komprehensif demi perubahan masyarakat menjadi lebih demokrastis.

Secara umum tulisan ini berasumsi bahwa salah satu kunci kemajuan bangsa Indonesia

${ }^{76}$ M. Nur Kholis Setiawan, Akar-akar Pemikiran Progresif dalam Kajian al-Qur'an (Yogyakarta: eLSAQ Press, 2008), h. 27. 
Budhy Munawar-Rahman: Masa Depan Wajah Islam Indonesia...

terletak pada penerapan yang benar ide demokrasi pada praktik sosial politik di Indonesia.

Para pemikir Islam Moderat-Progresif menyadari bahwa Pancasila sebagai dasar negara Indonesia dirumuskan berdasarkan masyarakat yang majemuk, yang meliputi perbedaan suku, ras dan agama. Karena itu, maka Pancasila harus bisa diterima oleh semua umat beragama, dan karena itu pula tidak bisa disebut bahwa Pancasila adalah "sebuah konsep negara Islam", dalam arti negara agama. Upaya lembaga-lembaga Islam ModeratProgresif dalam memperjuangkan gagasan tentang pentingnya demokrasi dalam masyarakat Indonesia yang majemuk melalui diseminasi diskursus ini ke wilayah publik merupakan hal yang menarik perhatian saya, sebagai suatu proses "philosophy in practice". demokrasi penting, karena kemaslahatan bangsa lebih utama dari pada kepentingan kelompok, golongan atau ideologi agama tertentu. Misalnya, munculnya fenomena fundamentalisme keagamaan bahkan radikalisme ("Islam Marah") yang merupakan "musuh" para intelektual Islam Moderat-Progresif, sebetulnya merupakan reaksi terhadap ideologi-ideologi yang dianggap sekular. Fundamentalisme keagamaan dan radikalisme yang muncul akhir-akhir ini, yang cenderung otoriter dan tidak jarang berpotensi melakukan aksi-aksi kekerasan, harus segera di atasi dan diantisipasi secepat mungkin. Solusi itu adalah demokrasi. Bibit-bibit kekerasan, baik struktural maupun kekerasan langsung hampir pasti selalu muncul dari doktrin yang dipaksakan. $\mathrm{Hal}$ inilah yang mengundang sejumlah intelektual Islam Moderat-Progresif mencari alternatif lain, dan alternatif itu ada pada demokrasi.

Menurut mereka, sudah sangat memadai apabila model demokrasi Indonesia mendapat pendasaran yang tepat pada dasar negara kita, Pancasila, dan konstitusinya, UUD 1945. Sebab, dari sanalah spirit keislaman yang universal dan sekaligus penghargaan terhadap upaya merayakan perbedaan yang menjadi kenyataan keindonesiaan, terkomodir.

Selanjutnya para intelektual Islam ModeratProgresif melalui lembaganya masing-masing mencoba mengembangkan ide kebebasan. Adapun kebebasan (liberty, freedom) adalah pengakuan terhadap hak-hak sipil. Oleh karenanya, munculnya kebebasan selalu disertai dengan hukum (rule of law). Sebab, kebebasan tidak akan terjadi tanpa adanya aturan-aturan hukum. Kemudian kebebasan itu dalam kenyataannya selalu dibatasi oleh hak orang lain. Kebebasan tidak bisa dilaksanakan dengan mengganggu kebebasan orang lain. Kebebasan di sini berlaku untuk semua manusia, yaitu kebebasan dan hak-hak sipil (civil rights, civil liberties): seperti kebebasan berfikir, berpendapat, beragama, berkeyakinan, dst. Dalam soal kebebasan beragama dan berkeyakinan, para intelektual Islam Moderat-Progresif menyadari bahwa negara tidak boleh membagi masyarakat beragama menjadi masyarakat agama minoritas dan mayoritas, semuanya memperoleh hak yang sama. kebebasan beragama ditegaskan oleh para intelektual Islam Moderat-Progresif adalah bagian yang paling penting dari hak-hak sipil. Kebebasan beragama diletakkan pada tingkat individu, sehingga tidak mengenal istilah minoritas dan mayoritas. Maka pengarusutamaan dan diseminasi kebebasan yang dilakukan oleh para intelektual Islam Moderat-Progresif dapat dianggap sebagai sebuah usaha etis mensosialisasikan pandangan yang membebaskan diri dari otoritarianisme agama, yang dalam sejarah pemikiran Islam telah muncul dari bentuk ortodoksi hasil dari himpunan konsensuskonsesus besar dalam pemikiran Islam di bidang fiqih, kalam, dan tasawuf yang telah menghegemoni dan mendominasi keberagamaan umat Islam Indonesia.

Selanjutnya para pemikir Islam ModeratProgresif menyadari bahwa kemajemukan atau pluralitas itu merupakan kenyataan dan, bahkan, makin lama makin menjadi keharusan. Artinya, masyarakat itu memang sedang menuju ke pluralitas. Untuk mengatur pluralitas ini menurut mereka diperlukanlah suatu dan pandanganpandangan etis pluralisme. Sebab, tidak bisa dipungkiri, pluralitas mengandung bibit perpecahan. Justru karena ancaman perpecahan inilah diperlukan sikap toleran, keterbukaan, dan kesetaraan. Inilah menurut mereka inti dari gagasan pluralisme yang diarusutamakan dan didiseminasi oleh para intelektual Islam ModeratProgresif kepada masyarakat. Dengan paham etis pluralisme setiap orang memperoleh kebebasan yang sama, adil dan setara. Tetapi juga dianjurkan untuk melakukan dialog saling pemahaman, toleransi, dan pengembangan sikap-sikap beradab 
(civility). Pluralisme ini juga tercermin dalam Pancasila yang terdiri dari berbagai ideologiideologi besar dunia tetapi intinya adalah paham kegotong-royongan, kekeluargaan dan kebersamaan. pluralisme sebagai paham filosofis dan etis inilah agaknya yang tidak dipahami oleh MUI. Dalam masyarakat yang majemuk, dan di sebuah negara yang "sekular," negara tidak berhak menyatakan bahwa agama yang satu benar, dan agama yang lain salah atau "sesat dan menyesatkan" seperti yang dituduhkan MUI kepada Ahmadiyah. Artinya, semua agama harus dianggap benar, yaitu benar, menurut keyakinan pemeluk agama masing-masing. Sebab prinsip etis ini merupakan landasan bagi keadilan, persamaan hak dan kerukunan antarumat beragama. Jika semua agama dianggap baik, maka orang terdorong untuk saling belajar, jika tidak, orang pasti akan bertahan dengan agamanya sendirisendiri. Dari sinilah pluralisme memberikan kondisi saling menyuburkan (cross vertilasation) dari iman masing-masing. Karena itulah bagi kalangan Islam Moderat-Progresif, pluralisme begitu diperlukan karena akan memberikan efek dinamika dan mendorong setiap individu untuk menyempurnakan kepercayaannya masingmasing, dengan mengambil pelajaran dari pengalaman pemeluk agama lain. pluralisme di samping mengakui perbedaan juga menganjurkan dialog. Di dalam dialog itu manusia berusaha saling memahami dan saling mengapresiasi. Tanpa pandangan pluralis, menurut Kalanga Islam Moderat-Progresif kerukunan umat beragama tidak mungkin terjadi. Demikian juga tanpa pluralisme, di mana keyakinan masyarakat didominasi oleh keyakinan hegemonik, seperti keyakinan para ulama MUI, maka kebebasan beragama akan terberangus dan hilang dari bumi Indonesia. Padahal yang mendasari Pancasila itu adalah pluralisme yang tersimpul dalam istilah "bbineka tunggal ika". Pluralisme, lewat Pancasila, adalah infrastruktutr budaya dari persatuan Indonesia, demokrasi kerakyatan dan keadilan sosial yang berdasar Ketuhanan yang Mahaesa dan kemanusiaan yang adil dan beradab.

Demikianlah, demokrasi dalam arti luas merupakan dasar bagi kebebasan beragama dan peranan agama di ruang publik. Ide Islam dan demokrasi ini diperjuangkan oleh sejumlah lembaga Islam, baik yang muncul dari kalangan atau tradisi NU maupun Muhammadiyah, seperti JIL, ICIP, LSAF, P3M, TWI, Maarif Institute, JIMM, Paramadina, LAKPESDAM, Kapal Perempuan, Fahmina, Rahima, dan seterusnya maupun jaringan STAIN/IAIN/UIN, dengan tujuan etis menjamin otonomi masyarakat sipil dan penyelenggaraan kehidupan beragama yang toleran dan sekaligus dinamis. Mereka melakukan pengarusutamaan dan diseminasi Islam dan demokrasi melalui berbagai program, misalnya kampanye melalui media, mimbar ilmiah, talk show, penerbitan buku, advokasi intelektual dan gerakan untuk keadilan sosial, publikasi gagasan dan wacana keislaman yang inklusif, toleran dan berwawasan pluralisme dan multikultural serta menggalang jejaring di kalangan intelektual Islam Moderat-Progresif, lintas agama, etnik dan relasi dengan berbagai lembaga yang memiliki kepedulian yang sama dalam tujuan etis pembebasan, mewujudkan demokrasi dan perubahan sosial berkeadilan dan berkeadaban.

Peranan lembaga-lembaga Islam ModeratProgresif di atas sangat penting, apalagi Islam di Indonesia dewasa ini makin kuat diasosiasikan dengan gerakan kekerasan dan bahkan terorisme ("Islam Marah"). Padahal Islam dipercaya membawa misi menciptakan rahmat bagi segenap manusia ("Islam Ramah"). Oleh karenanya, model Islam dan demokrasi Indonesia harus mendapat pendasaran yang tepat pada dasar negara kita, yaitu Pancasila, dan konstitusinya, UUD 1945. Menolak ide Islam dan demokrasi sebagaimana dilakukan para intelektual Islam Fundamentalis dan Radikal adalah sesuatu yang berbahaya, dan mengancam Negara Kesatuan Republik Indonesia (NKRI). Karena akan menimbulkan sakralisasi negara (yang mau mereka perjuangkan, yaitu "negara Islam") yang sebetulnya merupakan masalah duniawi, bukan akidah.

Hal lain yang diluruskan oleh para intelektual Islam Moderat-Progresif adalah pemahaman tentang Syariat Islam. Syariat Islam sebagai way of life seharusnya didasarkan pada tujuan syariat, yakni melindungi kebebasan, melindungi hak hidup, melindungi kehormatan individu, melindungi hak milik, dan menjamin regenerasi manusia. Jika syariat itu bertentangan dengan tujuannya, maka syariat itu harus ditinggalkan. Ketika agama mengambil alih peran 
publik negara, maka akan tercipta produk hukum yang personal. Ini sangat berbahaya dan harus diantisipasi. Solusinya adalah demokrasi. Islam dan demokrasi inilah yang telah dikembangkan oleh para Pemikir Islam Moderat-Progresif dalam "proyek-proyek pemikiran Islam".

Seperti sudah kita lihat, kemunculan intelektual Islam Moderat-Progresif di Indonesia, baik dari kalangan NU maupun Muhammadiyah, telah menumbuhkan harapan berkembangnya kembali tradisi pemikiran umat Islam yang dibutuhkan untuk menghadapi tantangan zaman. Kaum muda kritis yang banyak didominasi oleh intelektual muda dari tradisi NU dan Muhammadiyah, atau lebih luas yang berkultur "tradisional" dan "modernis" ini, boleh dikatakan ingin melanjutkan tradisi intelektual kritis yang telah dibangun oleh para senior mereka. Tradisi kritis yang sejak awal telah ditata oleh generasi intelektual "jilid pertama"-meminjam analisis Indonesianis Greg Barton, yaitu Nurcholish Madjid, Abdurrahman Wahid, Djohan Effendi, Ahmad Wahib, dan masih bisa ditambah M. Dawam Rahardjo, A. Syafii Maarif, yang semuanya dikenal masuk dalam gerbong "Islam Liberal-Progresif" atau "Neo-Modernisme Islam" ${ }^{\text {77 }}$ - dilanjutkan oleh intelektual progresif "jilid kedua"-seperti Azyumardi Azra, Komaruddin Hidayat, Dien Syamsuddin, Amin Abdullah, Bahtiar Effendy, Moeslim Abdurrahman, Munir Mulkhan, Jalaluddin Rakhmat, dan M. Syafi'i Anwar, dan seterusnya. Kedua generasi ini telah menjadi pendorong bagi intelektual muda progresif dari tradisi NU maupun Muhammadiyah kini untuk menggerakkan aktivisme intelektual mereka lebih dinamis. Tak hanya itu, keberadaan mereka juga diharapkan akan membantu mempercepat perubahan cara berpikir umat Islam yang selama ini berjalan sangat lamban. Selama ini umat Islam mengalami kemandekan berpikir disebabkan oleh memudarnya rasionalisme dalam pemikiran Islam—atau dalam istilah A. Syafii Maarif, "umat Islam telah berhenti berpikir selama 1000 tahun ini!"

77 Ahmad Baso, "Neo-Modernisme Islam Versus Post-Tradisionalisme Islam", dalam Jurnal Tashwirul Afkar, Edisi No. 10 Tahun 2001, h. 25. Lihat juga, tulisan Ahmad Baso yang lain, "Islam Liberal sebagai Ideologi: Nurcholish Madjid versus Abdurrahman Wahid”, Jurnal Gerbang, Vol. 06, No. 03, Februari-April 2000, h. 117-131.
Dalam pandangan M. Dawam Rahardjosalah satu mentor semua pemikir Islam ModeratProgresif-munculnya intelektual muda progresif baik di kalangan NU maupun Muhammadiyah pada dasarnya adalah melanjutkan pandanganpandangan senior mereka, yang mempunyai pemikiran-pemikiran baru dan dielaborasi sendiri oleh pemikir muda progresif ini, terutama terkait dengan isu-isu mengenai hubungan agama dan negara (sekularisme), kebebasan berpikir (liberalisme), pluralisme, hak asasi manusia, demokrasi, kesetaraan gender, dan seterusnya. ${ }^{78}$ Pemikir muda moderat-progresif (generasi ketiga) ini menurut Dawam, tertarik ikut memikirkan persoalan-persoalan yang berkembang di masyarakat. Hal ini memenuhi harapan Nurcholish, sebagaimana yang pernah dikatakannya pada tahun 1970-an, bahwa seharusnya ada di kalangan generasi muda yang menjadi penerus. Sekarang mimpi Nurcholish menjadi kenyataan. Bahkan, isu-isu yang ditawarkannya jauh lebih kompleks dari pada isu yang pernah dilontarkan Nurcholish Madjid pada masanya. Tentu saja, ini merupakan hasil dari proses yang cukup panjang. ${ }^{79}$

Dawam memandang bahwa pemikir muda moderat-progresif sekarang ini berani berpikir berbeda, dan berani melakukan instropeksi terhadap organisasi masing-masing, seperti NU dan Muhammadiyah. Sehingga karena itu Dawam optimis mereka akan menjadi tokoh-tokoh pemikir muda moderat-progresif. Yang menarik adalah mereka merupakan tokoh-tokoh muda yang benar-benar menguasai khazanah Islam klasik, dan mampu mengelaborasi dalam bingkai kekinian dan kedisinian, yang menyaratkan berbagai penguasaan terhadap sejumlah pendekatan dalam ilmu pengetahuan modern, misalnya, ilmu-ilmu sosial, dan hermeneutika. Munculnya pemikir muda progresif dalam payung organisasi besar seperti NU dan Muhammadiyah dapat dilihat sebagai counter begemony terhadap arus konservatisme baik di kalangan NU maupun Muhammadiyah.

Dengan kata lain, ketika organisasiorganisasi Islam yang besar seperti Muhammadiyah dan NU tidak bisa lagi

78 Wawancara dengan M. Dawam Rahardjo, Oktober 2007

${ }^{79}$ Ibid. 


\section{NUSANTARA; Journal for Southeast Asian Islamic Studies \\ Vol. 15, No. 1, Juni 2019}

melakukan pembaruan, maka muncullah LSMLSM yang dikembangkan oleh mereka sebagai alternatif. Pemikir muda Islam Moderat-Progresif yang lahir melalui LSM ini membuat kritik-kritik, karena wacana yang dikembangkan oleh organisasi induk mereka dianggap sudah tidak relevan lagi.

\section{DAFTAR PUSTAKA}

Ahmad Gaus AF, "Islam Progresif: Wacana Pasca Arus Utama (Peta Pemikiran dan Gerakan Islam di Indonesia)", dalam, Jurnal Tashwirul Afkar, Edisi No. 22 Tahun 2007

Ahmad Baso, "Neo-Modernisme Islam Versus Post-Tradisionalisme Islam", dalam Jurnal Tashwirul Afkear, Edisi No. 10 Tahun 2001,

Ahmad Baso, "Islam Liberal sebagai Ideologi: Nurcholish Madjid versus Abdurrahman Wahid", Jurnal Gerbang, Vol. 06, No. 03, Februari-April 2000

Andree Feillard, NU vis-a-vis Negara; Pencarian Isi, Bentuk dan Makna (Yogyakarta: LKiS, 1999)

Bahtiar Effendy, Islam dan Negara Transformasi Pemikiran dan Praktik Politik Islam di Indonesia (Jakarta: Paramadina, 1998)

Elza Peldi taher (ed) Kontekstualisasi Ajaran Islam 70 Tahun Prof. Dr. H. Munawir Sjadzali (Jakarta: Paramadina, 1995)

Fuad Jabali dan Jamhari, IAIN, Modernisasi Islam di Indonesia (Jakarta: Logos, 2002)

Harun Nasution, Islam Rasional Gagasan dan Pemikiran(Bandung: Mizan, 1995)

Harun Nasution "Sudah Saatnya IAIN Diubah Menjadi Universitas", Republika 5 Januari 1996.

Herry Sucipto (ed.), Islam Madzhab Tengah, Persembahan 70 Tabun Tarmidzi Taher (Jakarta: Grafindo, 2007)

Jamhari dan Jajang Jahroni (peny.), Gerakan Salafi Radikal di Indonesia (Jakata: Rajawali Pers, 2004)

Mohamad Ali, Islam Muda Liberal, Post-Puritan, Post-Tradisional (Yogyakarta: Apeiron Philotes, 2006)

Muhamad Ali, "Gerakan Islam Moderat di Indonesia Kontemporer" dalam Rizal Sukma dan Clara Juwono (ed.), Gerakan dan Pemikiran Islam di Indonesia Kontemporer (Jakarta: CSIS, 2007)

Marzuki Wahid, "Post-Tradisionalisme Islam: Gairah Baru Pemikiran Islam di Indonesia", dalam Jurnal Tashwirul Afkar, Edisi No. 10 Tahun 2001 
Budhy Munawar-Rahman: Masa Depan Wajah Islam Indonesia...

Martin van Bruinessen, NU: Tradisi, Relasi-relasi Kuasa, Pencarian Wacana Baru (Yogyakarta: LKiS, 1997)

Mohammad Arkoun, Membongkar Wacana Hegemonik dalam Islam dan Post Modernisme (Surabaya: Al-Fikr, 1992).

M. Amin Abdullah MUI, "Fatwa dan Otoritas Keagamaan di Indonesia" dalam Ahmad Suaedy dan Rumadi, Kala Fatwa Jadi Penjara (Jakarta: The Wahid Institute, 2006)

M. Nur Kholis Setiawan, Akar-akar Pemikiran Progresif dalam Kajian al-Qur'an (Yogyakarta: eLSAQ Press, 2008)

Mukti Ali, Imu Perbandingan Agama (Yogyakarta: IAIN Sunan Kalijaga Press, 1988

Zuhairi Misrawi dan Novriantoni, Doktrin Islam Progresif Memahami Islam Sebagai Ajaran Rahmat (Jakarta:LSIP, 2004),

Zuly Qodir dkk. (ed.), Mubammadiyah Progresif Manifesto Pemikiran Kaum Muda (Yogyakarta: Lesfi-JIMM, 2007)

Nur Khalik Ridwan, Santri Baru, Pemetaan, Wacana Ideologi dan Kritik (Yogyakarta: Gerigi Pustaka, 2004)

Fuad Fachruddin, Agama dan Pendidikan Demokrasi Pengalaman Mubammadiyah dan Nahdlatul Ulama (Jakarta: INSEP, 2006)

Nuriyati Samatan, Dinamika Pemikiran Kalangan Muda Nabdlatul Ulama, Tulisan pada Program Pascasarjana Universitas Padjadjaran, Bandung 2007, h. 222-223.

La Ode Ida, "NU Muda, Kaum Progresif dan Sekularisme Baru" (Jakarta: Erlangga, 2004)

Nurcholish Madjid, "Jangan Tinggalkan Masa Lalu”, dalam Republika, Jum'at 25 Juni 1999,

Yasmin, Modernisasi Pesantren Kritik Nurcholish Madjid Terhadap Pendidikan Islam Tradisional (Jakarta: Quantum Teaching, 2005)

Ken Miichi, "Kiri Islam, Jaringan Intelektual dan Partai Politik: Sebuah Catatan Awal", dalam Jurnal Tashwirul Afkear, Edisi No. 10 Tahun 2001.

Rumadi, Post Tradisionalisme Islam: Wacana Intelektualisme dalam Komunitas NU (Jakarta: Fahmina Institute, 2008).
Pradana Boy ZTF dan M. Hilmi Faiq (ed), Kembali ke al-Qur'an, Menafsir Makna Zaman (Malang: UMM Press, 2004).

Zuly Qodir dkk. (ed.), Muhammadiyah Progresif Manifesto Pemikiran Kaum Muda' (Yogyakarta: Lesfi-JIMM, 2007)

Zuly Qodir, Islam Syariah vis a vis Negara, Ideologi Gerakan Politik di Indonesia (Pustaka Pelajar: Yogyakarta, 2007)

M. Amin Abdullah, Islamic Studies di Perguruan Tinggi Pendekatan Integratif-Interkonektif (Yogyakarta: Pustaka Pelajar, 2006)

Kuntowijoyo, Muslim Tanpa Masjid Esai-esai Agama, Budaya, dan Politik dalam Bingkai Strukturalisme Transendental (Bandung: Mizan, 2001)

Kusmana (Ed.), Proses Perubahan IAIN Menjadi UIN Syarif Hidayatullah Jakarta, Rekaman Media Massa (Jakarta: UIN Jakarta Press, 2002) 